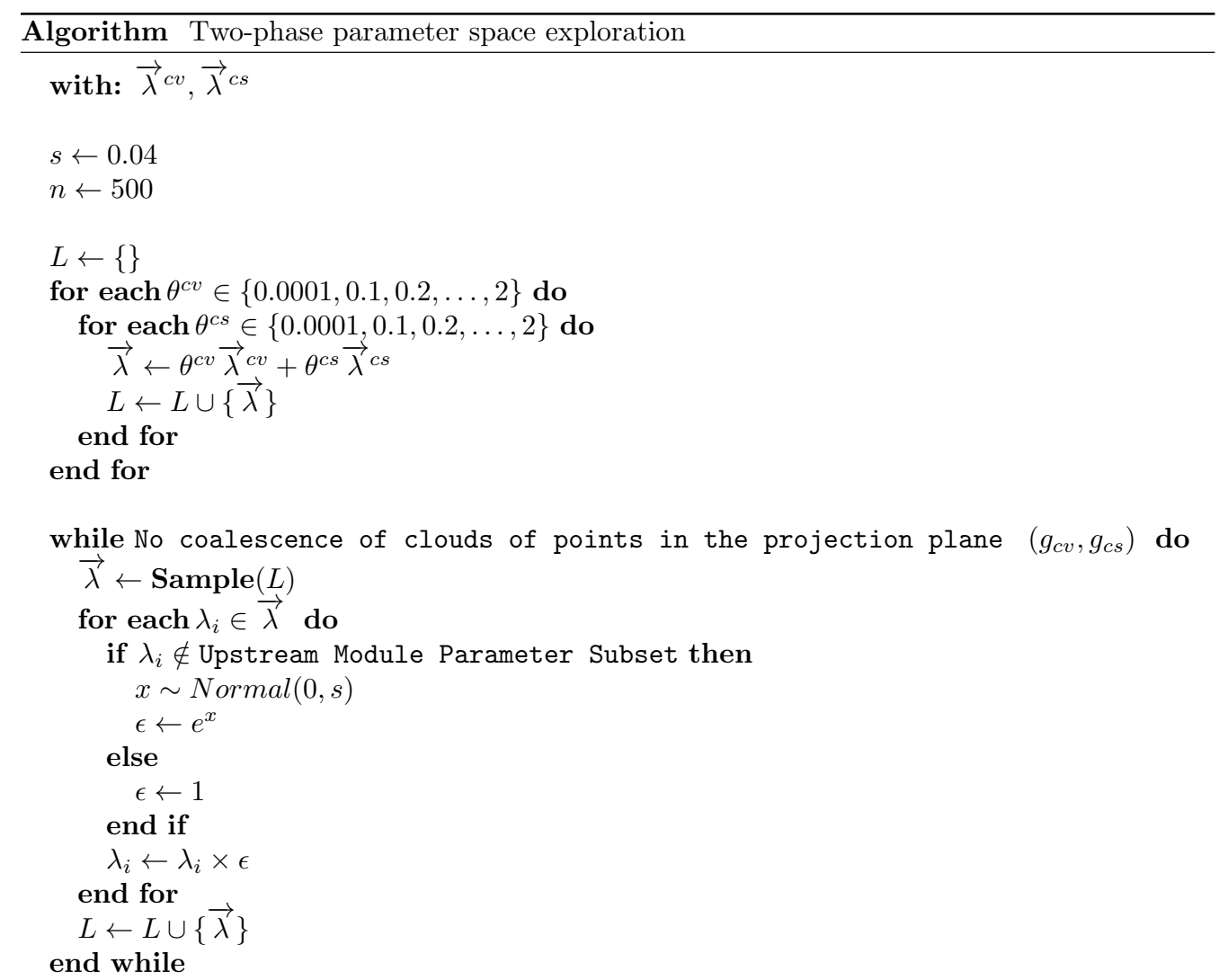

\title{
Phase 2
}

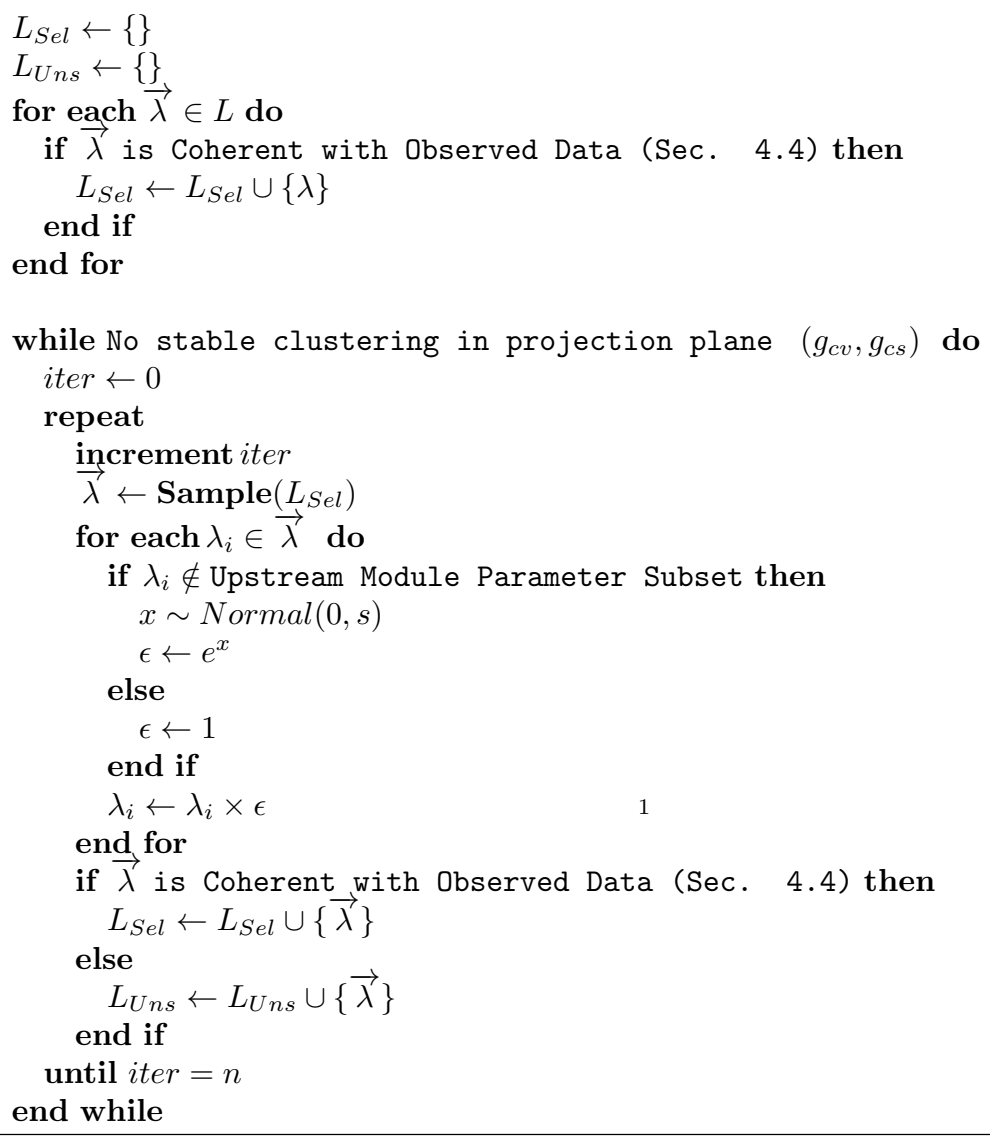

